\title{
HUMAN RESOURCE MANAGEMENT IN IMPROVING THE QUALITY OF TEACHERS IN INDONESIAN ISLAMIC PRIMARY EDUCATION INSTITUTIONS
}

\author{
Makherus Sholeh ${ }^{1}$, Raihanatul Jannah ${ }^{2}$, Khairunnisa ${ }^{3}$, \\ Nur Kholis ${ }^{4}$, Ghada Tosson ${ }^{5}$
}

UIN Antasari Banjarmasin, Indonesia ${ }^{1,2,3}$,

UIN Sayyid Ali Rahmatullah Tulungagung, Indonesia ${ }^{4}$, Beni-Suef University, Egypt ${ }^{5}$

E-mail: makherus@uin-antasari.ac.id ${ }^{1}$,raihanah69@gmail.com ${ }^{2}$, khrairunnisaahmad249@gmail.com ${ }^{3}$, nurkholisblt@yahoo.com ${ }^{4}$, ghada_tosson@yahoo.com ${ }^{5}$

DOI: 10.14421/al-bidayah.v13i1.628

\begin{abstract}
Human Resource Management (HRM) problems are familiar at all educational institutions, such as the Islamic Basic Educational Institution. This study aims to reveal and introduce the concept of HRM in improving the quality of teachers at the SDI (islamic elementary school) Qurrota A'yun Tulungagung, Indonesia, to show the importance of HR in improving the quality of teachers in Islamic Primary Educational Institutions. Furthermore, this research involves ten informants, including a school principal, teachers, committees, parents, and community leaders. Subsequently, data were collected through in-person interviews (via telephone and online by WhatsApp messaging services), participant observation, and documentation. The results show the process of human resource management in improving the quality of teachers through planning, training, and evaluation. Firstly, the planning strategy is conducted through preservice education or recruitment, while the training strategy is conducted by making on-the-job and offthe-job training programs. Lastly, Every week, semester, and year, the evaluation is completed, and rewards are given. In conclusion, the findings imply that human resource management has an important role in determining the quality of teachers.
\end{abstract}

Keywords: HR management; Indonesia; institutions; islamic basic education; teacher quality

\section{INTRODUCTION}

Globalization and technological developments promote the competition for highquality human resources in Islamic primary educational institutions. HRM is a formal system within the organization to effectively maximize the potential possessed by humans through policies, training practices, and assessments that affect employee behavior, attitudes, norms, and performance. ${ }^{1}$

However, research from the Center for Educational and Cultural Policy shows the limitations of school principals as the main force behind HR in Indonesia, which include little insight, low work productivity, and undeveloped quality culture. From these data, such limitations contradict the managerial, personal, social, entrepreneurial, and

${ }^{1}$ Alwiya Allui and Jolly Sahni, "Strategic Human Resource Management in Higher Education Institutions: Empirical Evidence from Saudi," Procedia - Social and Behavioral Sciences 235, no. October (2016): 361-71, https://doi.org/10.1016/j.sbspro.2016.11.044. 
supervisory competencies that a school principal must possess as a human resource driver in his institution. Therefore, the role of the principal in HRM is vital in ensuring that the quality of human resources can increase organizational productivity. The quality of teachers has a vital role in realizing this vision and mission. ${ }^{2}$ In practice, David A. DeCenzo and Stephen Robbins explained HRM, which consists of planning, training, and evaluation. ${ }^{3}$

Based on human resource management and development theory, three major groups of HRM knowledge were confirmed, including expatriation management, global human capital, and international human resources policies and practices. ${ }^{4}$ According to Clint Chadwick, this development created a significant gap from the literature review on applying human resource management practices, narrowing the scope of HRM. ${ }^{5}$

Many previous research results on HRM practices in higher education regarding the importance of effective human resource management, such as Allui and Sahni, Diturije Ismailia and Muharem Etemib, Meryem Bastas and Zehra Altinay and Nakpodia. ${ }^{6}$ However, few HRM studies are carried out in primary education institutions, such as Erni Munastiwi and Sri Puryono. ${ }^{7}$

In the context of improving the quality of teachers, several research results can be adopted by school principals, such as School-based Professional Development, Training

${ }^{2}$ Benjamin Fauth et al., "The Effects of Teacher Competence on Student Outcomes in Elementary Science Education: The Mediating Role of Teaching Quality," Teaching and Teacher Education 86 (2019): 102882, https://doi.org/10.1016/j.tate.2019.102882.

${ }^{3}$ David A. DeCenzo, Human Resource Management, 10th Ed., (Hoboken, N.J.: Wiley, 2010). 110.

${ }^{4}$ Alice L. Epstein and Gary H. Harding, "Chapter 48 - Management Styles and Human Resource Development," in Clinical Engineering Handbook (Second Edition), ed. Ernesto Ladanza (Cambridge, Massachusetts: Academic Press, 2020), 308-20, https://doi.org/10.1016/B978-0-12-813467-2.00049-3. Di Fan et al., "Mapping the Terrain of International Human Resource Management Research over the Past Fifty Years: A Bibliographic Analysis," Journal of World Business 56, no. 2 (2021), https://doi.org/10.1016/j.jwb.2020.101185.

5 Clint Chadwick, "The Vital Role of Strategy in Strategic Human Resource Management Education," Human Resource Management Review 15, no. 3 (2005): 200-213, https://doi.org/10.1016/j.hrmr.2005.11.003. Fan et al., "Mapping the Terrain of International Human Resource Management Research over the Past Fifty Years: A Bibliographic Analysis."

6 Allui and Sahni, "Strategic Human Resource Management in Higher Education Institutions: Empirical Evidence from Saudi.", Diturije Ismaili and Muharem Etemi, "Human Resources Management at South East European University as a New Model of Higher Education in the Republic of Macedonia," Procedia - Social and Behavioral Sciences 2, no. 2 (2010): 5125-29, https://doi.org/10.1016/j.sbspro.2010.03.833. Meryem Bastas and Zehra Altinay, "Employment for Disability: Human Resources Management in Higher Education for Quality," International Journal of Disability, Development and Education 66, no. $6 \quad$ (2019): 610-15, https://doi.org/10.1080/1034912X.2019.1643456. E. D. Nakpodia, "Human Resource Management in School Administration in Delta State Nigeria," Journal of Social Sciences 23, no. 3 (2010): 179-87, https://doi.org/10.1080/09718923.2010.11892827.

${ }^{7}$ Erni Munastiwi and Sri Puryono, "Unprepared Management Decreases Education Performance in Kindergartens during Covid-19 Pandemic," Heliyon 7, no. 5 (2021): e07138, https://doi.org/10.1016/j.heliyon.2021.e07138. 
and Follow-up Procedures, Collaborative Information, and Embedding Practices into the Daily Lives of Teachers. ${ }^{8}$

In practice, six program models that improve the quality of teachers, which include seminars, training, and workshops, participation in conferences, formation of reading groups, and peer observation. Others include writing a teacher's daily journal, project work, implementing classroom action research (CAR), creating a teaching portfolio, and mentoring. ${ }^{9}$

Therefore, this study aims to analyze and explain how HRM improves the quality of teachers in Islamic primary education institutions. As a result, it adopts the concept of implementing an effective HRM. According to Robbins, HRM in practice improves the quality of teachers at Islamic educational institutions and consists of three segments: the planning, training, and evaluation segment.

\section{RESEARCH METHODS}

This research was conducted at SDI Qurrota A'yun Tulungagung, East Java, Indonesia, from January 3rd - August 10th, 2020. This Islamic Elementary School is distinguished by implementing four curricula, including the Cambridge curriculum, curriculum-13, the Madin curriculum, and the Madrasah Ibtidaiyah curriculum. Furthermore, individual teachers and students achieve a great deal in academic and nonacademic areas every year. Therefore, this research determines the HRM process in improving teachers' quality at SDI Qurrota A'yun, Tulungagung Regency, East Java, Indonesia, using a qualitative descriptive approach. ${ }^{10}$ The researcher identified eight informants who play essential roles in HR at SDI Qurrota A'yun Tulungagung, including one principal (KS), seven teachers (G1, G2, G3, G4, G5, G6, G7), one committee (K), 1 Student Guardian (WM), and Community Leader (TM). Also, data were collected through interviews, participant observation, and documentation.

Information was collected through in-depth interviews using structured and unstructured questions. The methods used in extracting interview information are telephone, face-to-face, and online using the WhatsApp application. Furthermore, the interview data were recorded using a telephone recorder, and notes were taken using the WhatsApp application.

${ }^{8}$ Trisha Nishimura, "Effective Professional Development of Teachers: A Guide to Actualizing Inclusive Schooling," International Journal of Whole Schooling 10, no. 1 (2014): 19-42, https://eric.ed.gov/?id=EJ1016781.

${ }^{9}$ Jack C. Richard and C. Lockhart, Reflective Teaching in Second Language Classrooms (London: Cambridge University Press, 2000). Gabriel Diaz and Maggioli, Teacher Centered Professional Development, Healthcare Executive, vol. 21 (Virginia: Association for Supervision and Curriculum Development (ASCD), 2004).

10 Andi Prastowo, Metode Penelitian Kualitatif Dalam Perspektif Rancangan Penelitian (Yogyakarta: Ar-Ruzz Media, 2012). 186 
The data obtained were then analyzed qualitatively to explain the general description of HRM activities in improving the quality of teachers. Subsequently, qualitative analysis was carried out thematically to explore and find the concept of HRM in the teachers' quality planning, development, and evaluation segment.

\section{RESULT AND DISCUSSION \\ RESULT}

\section{Teacher Quality Planning}

Recruitment or pre-service education is seen as a shortcut for the SDI Qurrota A'yun Tulungagung institution to have high-quality human resources. The recruitment system was implemented since there were vacant positions left by teachers who were accepted by Civil Servants (PNS), moved to other institutions, or were dismissed. ${ }^{11}$ The teacher recruitment system in improving the quality of teachers is conducted before the new school year and communicated in the RKTS (Annual School Work Meeting) forum to analyze the institution's needs internally and externally. ${ }^{12}$

The recruitment process is published through social media such as WhatsApp groups, Facebook, school websites, YouTube, and school relations. ${ }^{13}$ The informant stated as follows:

"There are two concepts to get high-quality teachers: recruitment and training. I recruited qualified teachers by paying attention to good academic grades. Even if they do not have good academic grades, they must have the ability to speak English. The mandatory requirements are knowledge of Islam, tartil reciting Alquran, and fluent English, both written and spoken."14

The implementation of the recruitment system is carried out through external and internal sources and by going through the selection stages.

Firstly, the administrative selection is based on the applicant's undergraduate certificate. Since this school follows the Cambridge curriculum, the principal prioritizes applicants who have an English qualification. ${ }^{15}$ Secondly, a Written test is done to examine prospective teachers' academic abilities and talents both in English and Islam. ${ }^{16}$

\footnotetext{
${ }^{11}$ Informant G1,G2,G3

12 Informant G1,G3,G6

${ }^{13}$ Infomant K, WM, TM

${ }^{14}$ Informant KS

${ }^{15}$ Informant G1, G2,G3

${ }^{16}$ Informant G4, G5,G6
} 
Thirdly, Psychological tests are conducted to test the intelligence and personality abilities of prospective teachers. ${ }^{17}$ Lastly, An interview is held to determine the ability of prospective teachers to read the Kitab Kuning and recite Akhlaq Banin and Banad Books to be placed in the ICP class that implements the Cambridge curriculum. At this stage, teachers are subjected to micro-teaching as well as an Alquran recitation test. ${ }^{18}$

Job placement required by SDI Qurrota A'yun Tulungagung began with a threemonth trial as a GTT (non-permanent teacher). During the probationary period, teachers can carry out tasks professionally according to the assigned tasks. Subsequently, they will be appointed as GTY (permanent teachers of the foundation) with a work agreement letter for five years, after which they will be reconsidered for extension or not. ${ }^{19}$

From the description above, human resource planning for improving teacher quality begins with conducting a needs analysis and recruitment published in social media and relations, followed by various stages of administrative selection, reading and writing tests, psychological tests, and interviews according to the needs of the institution in realizing the vision and the mission of the institution, and job placement.

\section{Teacher Quality Training}

The training program in improving the quality of teachers at SDI Qurrota A'yun Tulungagung is carried out in two methods: on-the-job and off-the-job training programs. Furthermore, the on-the-job training program is carried out during working hours, formally and informally, through webinars, seminars, workshops, internal and external training, job rotations, and socio-religious activities, ${ }^{20}$ as stated by the informant viz:

"Our institution's teacher quality improvement program is divided into the on-thejob training program and the off-the-job training program. On-the-job training programs consist of webinars, seminars, workshops, and training carried out internally and externally by institutions, job rotations, and socio-religious activities. Meanwhile, off the job training programs consist of KKG, continuing to higher education level, equalization studies, professional teacher education, and comparative study". ${ }^{21}$

SDI Qurrota A'yun teachers attended training activities, seminars, workshops, and webinars to strengthen information technology capabilities to actualize the institution's

\footnotetext{
${ }^{17}$ Informant G6, G7

${ }^{18}$ Informant G5, G7

${ }^{19}$ Informant KS, K and SK Document for Appointment of Non-permanent Teachers Foundation

${ }^{20}$ Informant K, G6, G4

${ }^{21}$ Informant G1,G2,G3,G4,G5, G6
} 
vision and mission and to face changing times during the COVID-19 pandemic. ${ }^{22}$ Mastery of ICT-based learning, mobile devices such as WhatsApp, google classroom, zoom, google meet, youtube are utilized as a form of institutional response in overcoming various problems faced and improving teachers' quality during the pandemic. ${ }^{23}$ Meanwhile, the seminar has been held to improve the quality of teachers in mastering English by inviting Simona Alexandra Hichert, a tutor from Germany. ${ }^{24}$

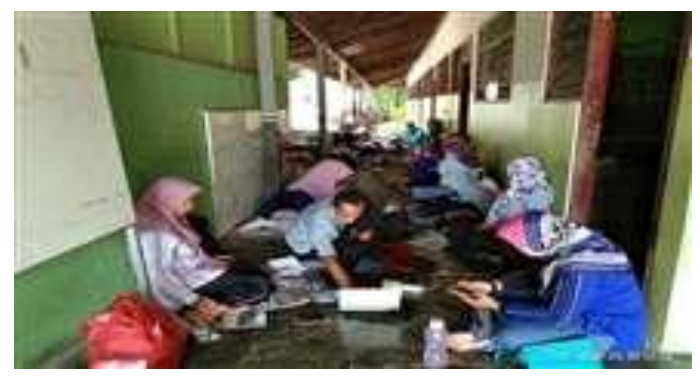

Internal training, IT Mastery in preparing Online learning

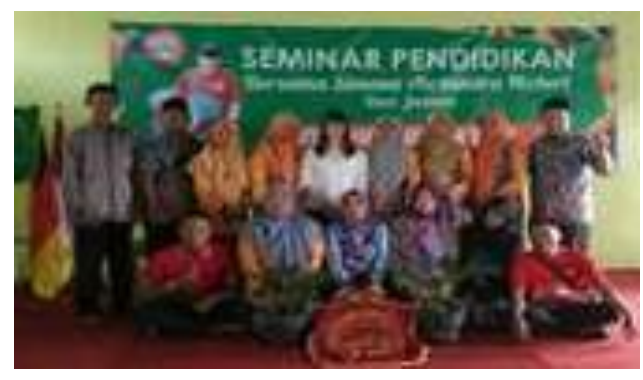

Capacity Building for English Tutor

Alexanda Hichert

Figure 1.

Internally held training and seminars

Job rotation and socio-religious activities are carried out to provide teachers with leadership experience. It fosters the spirit of leadership in individual teachers and develops teacher leadership capacity. Meanwhile, socio-religious activities are manifested in several agendas: environmental reforestation activities, scholarships, recitation of the morality of 'Banin and Banad' books, and PHBI (Islamic Holiday Celebration). ${ }^{25}$

Conversely, off-the-job training programs are carried out specifically outside of work, such as KKG, higher education, equivalency studies, professional teacher education, and comparative studies. ${ }^{26}$ According to the observations, four teachers had finished their higher education level, seven teachers had completed the equivalency study, and six teachers had already attended professional education and received certification. ${ }^{27}$

\footnotetext{
${ }^{22}$ Informant $\mathrm{K}$

${ }^{23}$ Informant K, G1,G2,G3, G4,G5,G6

${ }^{24}$ Informant KS, G1,G2,G3,G4,G5,G6

${ }^{25}$ Informant K, G1, G3, G6

${ }^{26}$ Informant $\mathrm{K}$

${ }^{27}$ Document
} 


\section{Teacher Quality Evaluation}

Evaluation of teacher quality is carried out periodically to implement the work (position), including the potential for progress. SDI Qurrota A'yun Tulugagung conducts teacher quality evaluations on a weekly, semester, and annual basis. The following are some informed comments:

"We conduct periodic evaluations for every week, semester, and year. Usually, we conduct evaluations every Saturday in the classroom or the meeting room. Weekly evaluations are used to solve learning problems. Semester evaluations are used to evaluate work programs, and annual evaluations are to evaluate teacher performance". 28

Firstly, Principals use weekly evaluations to control teacher performance in one week, such as conducting clinical supervision to discuss the completeness of lesson plans and resolving various problems encountered during the learning process. ${ }^{29}$ Secondly, school principals conducted semester evaluations is to evaluate teacher performance in implementing various school programs such as the on-the-job and off-the-job training programs. ${ }^{30}$ Thirdly, the annual evaluation is used to evaluate a teacher's performance for a year. This evaluation is divided into assessments of superiors, peer assessments, student assessments, and assessments of students' parents and guardians. ${ }^{31}$

The trigger for principals to improve teacher quality is to reward teachers who perform well as a form of appreciation, attention, and commitment from leaders to their members who continue to improve individual qualities. The form of reward given is both material and non-material. ${ }^{32}$

\section{DISCUSSION}

Based on the 2005-2025 Long Term National Education Development Plan, the 2025 vision will produce an intelligent and competitive Indonesian generation (Insan Kamil/Insan Plenary). Furthermore, article 10, paragraph 1 of the Law on Teachers and Lecturers and Decree of the Minister of Religious Affairs of the Republic of Indonesia Number 211 of 2011 stated that educators must have six competencies, which include pedagogic, professional, social, personal, spiritual, and leadership competencies, in order

\footnotetext{
${ }^{28}$ Informant KS

${ }^{29}$ Informant G3, G5

${ }^{30}$ Informant KS, G1,G2,G3,G4,G5,G6

${ }^{31}$ Informant G1,G2,G3,G4,G5,G6

${ }^{32}$ Informant KS, G1, G2, G3
} 
to actualize the 2021 vision. ${ }^{33} \mathrm{~A}$ human resource management model is needed to improve the quality of teachers and ultimately support these noble ideals.

Based on the findings above, there are differences in human resource management in improving teacher quality with the theory developed by Stephen Robbins and Marry Coulter, which includes stages such as recruitment, selection, orientation, training, performance management, compensation, and career development. ${ }^{34}$ Meanwhile, the pattern of HRM in improving the quality of teachers is as follows:

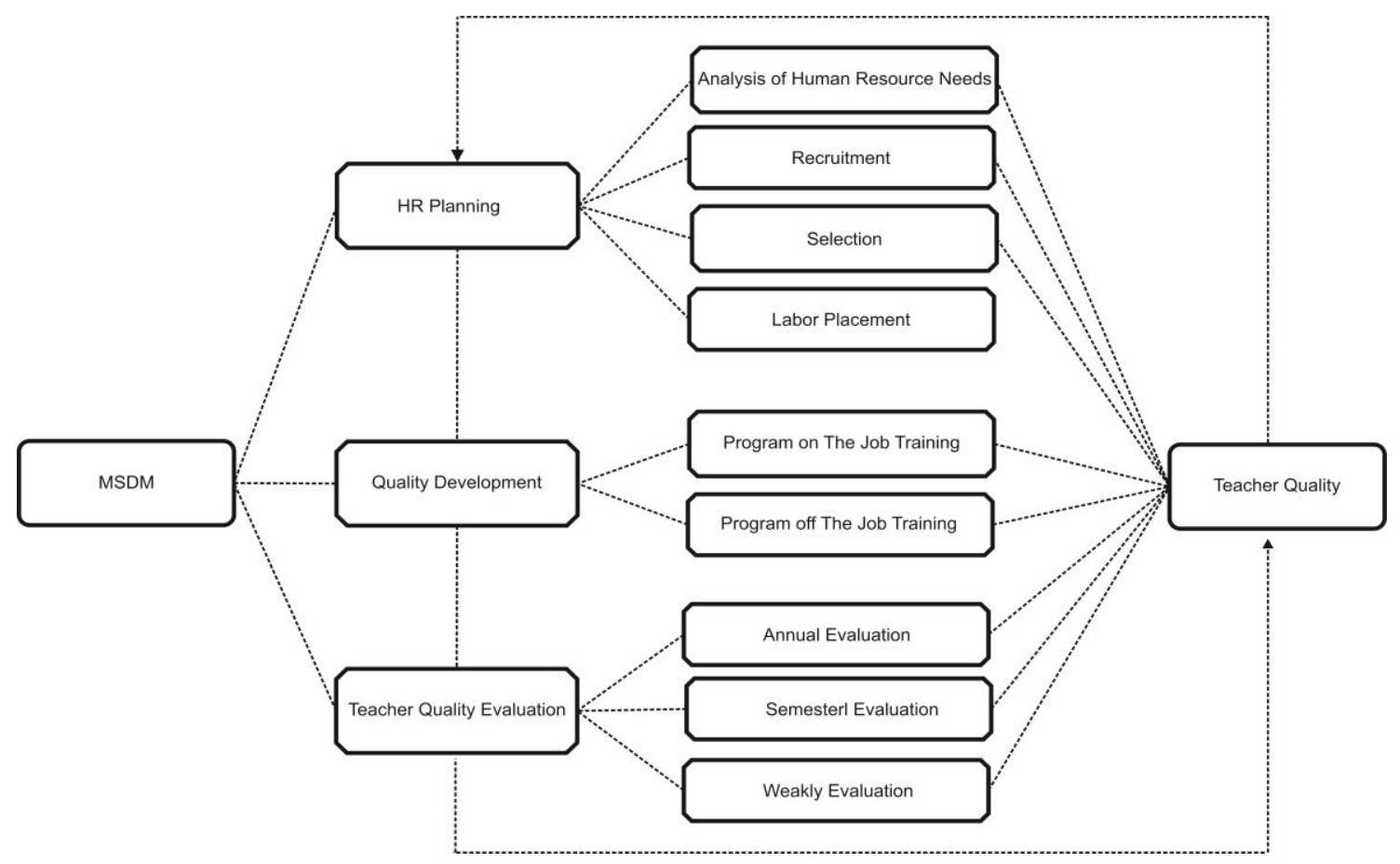

Figure 2.

Human resource management scheme

Planning for teacher quality improvement begins with carefully and intelligently diagnosing what strategies can improve teacher quality to meet expectations in each unit and school level. Furthermore, the principal of a primary education institution will realize what to do and how to do this through teacher quality planning. As a result, teacher quality continues to improve. ${ }^{35}$

${ }^{33}$ President of the Republic of Indonesia, "Teachers and Lecturers, Law of the Republic of Indonesia No. 14/2005" (State Secretariat of the Republic of Indonesia, 2005); Minister of Religious Affairs, "Guidelines for National Standards of Islamic Religious Education in Schools, Decree of Ministry of Religious Affair Number 22/2011" (Ministry of Religious Affair, Indonesia, 2011).

${ }^{34}$ Stephen P Robbins and Mary Coulter, Management, Thirteenth (Boston: Pearson, 2016). 266

${ }^{35}$ Sholeh Makherus, Achmad Patoni, and - Abd Aziz, "Peer Review Transformational Leadership: Principal's Idealized Influence in Improving Teacher Competence," Other (Tulungagung: -, 2021), http://repo.iain-tulungagung.ac.id/20906/. 
There are stages in planning human resource management at SDI Qurrota A'yun, which first includes analysis of HR needs. Needs analysis can be considered in policymaking in improving the quality of teachers through recruitment and program activities. According to Janet H. Marler and John W. Boudreau, analysis of HR needs has a low influence on organizational performance. ${ }^{36}$ The second stage involves recruitment, which comprises a system published on social media, making it easier for applicants and institutions to find potential teacher candidates. ${ }^{37}$

Thirdly, the selection is implemented through administrative selection, written and psychological tests, and interviews carried out by the leader who makes decisions for the ranks. Five standards need to be considered in the selection, including reliability, validity, generality, utilization, and legality. ${ }^{38}$ The fourth stage involves work placement to provide satisfaction in job placement. The leader can conduct a real job review, including the advantages and disadvantages of the assigned task.

Teacher quality training is a management function that needs to be done to improve, maintain, and improve performance. Subsequently, this activity can be carried out through on-the-job and off-the-job training programs. ${ }^{39}$ Teacher quality training is conducted to ensure that they can maintain their professional quality following the school's distinction.

The on the job training program implemented at SDI Qurrota A'yun Tulungagung includes webinars, seminars, workshops, training conducted internally and externally by the institution, job rotation, and socio-religious activities. Furthermore, Diaz and Maggioli explained that improving the quality of teachers is attainable through conferences and seminars (attending conferences and seminars), training, and workshops. ${ }^{40}$ On the other hand, job rotation aims to foster leadership spirit in individual teachers and develop teacher leadership capacity, which impacts school and teacher

\footnotetext{
36 Janet H. Marler and John W. Boudreau, "An Evidence-Based Review of HR Analytics," International Journal of Human Resource Management 28, no. 1 (2017): 3-26, https://doi.org/10.1080/09585192.2016.1244699.

${ }^{37}$ David A. DeCenzo, Human Resource Management. 7.

38 Chris Rowley and Keith Jackson, Human Resource Management: The Key Concepts (Oxfordshire: Routledge, 2010). 388, Raymond A. Noe et al., Human Resource Management: Gaining a Competitive Advantage, 9th ed. (Boston: McGraw-Hill Education, 2014). 132; Gary Dessler, Human Resource Management Fourteenth Edition (Boston; Montréal: Pearson, 2015). 200.

39 Elvi Rahmi, Achmad Patoni, and Sulistyorini Sulistyorini, "The Management of Human Resources Development in Increasing the Quality of Islamic Education Institutions," Al-Ta Lim Journal 27, no. 2 (2020): 166-78, https://doi.org/10.15548/jt.v27i2.624.

${ }^{40}$ Diaz and Maggioli, Teacher Centered Professional Development. 1-152
} 
performance through socio-religious activities carried out to build teacher self-efficacy to work seriously. ${ }^{41}$ Religious education has emerged as an essential dimension of the nation's moral health and as a factor that can affect human welfare. ${ }^{42}$

Meanwhile, the off-the-job training program includes KKG, higher education, comparative studies, equalization studies, and professional teacher education. The offthe-job training program emphasizes increasing teacher knowledge, specifically outside of work. More so, professional organizations have an important role in improving the quality of teachers by holding seminars, workshops, and training. ${ }^{43}$ Guo explained that highly qualified teachers positively impact the school and classroom environment, ${ }^{44}$ and also teacher consistency to study and pursue a higher education level affects teacher competence and quality. ${ }^{45}$ Furthermore, they develop individual and group relationships, provide mutual support, and participate actively in various activities with students, and build a conducive climate that allows teachers to work and develop their abilities to impact student achievement through comparative studies. ${ }^{46}$

41 Deborah Shea, Daniel S. Alemu, and M. Jacqueline Visser, "A Social Network Study of Transformational Teacher Influence," Teacher Development 24, no. 5 (October 19, 2020): 603-25, https:/doi.org/10.1080/13664530.2020.1818614; Viviane M. J. Robinson, "Embedding Leadership in Task Performance," in Leadership for Quality Schooling (London and New York: Routledge, 2001); Shea, Alemu, and Visser, “A Social Network Study of Transformational Teacher Influence." Ling Li and Yan Liu, "An Integrated Model of Principal Transformational Leadership and Teacher Leadership That Is Related to Teacher Self-Efficacy and Student Academic Performance," Asia Pacific Journal of Education 00, no. 00 (2020): 1-18, https://doi.org/10.1080/02188791.2020.1806036. Ying Guo et al., "The Effects of Teacher Qualification, Teacher Self-Efficacy, and Classroom Practices on Fifth Graders' Literacy Outcomes," The Elementary School Journal 107, no. 5 (2007): 499-503, https://doi.org/10.1086/518627. John A. Ross and Peter Gray, "Transformational Leadership and Teacher Commitment to Organizational Values: The Mediating Effects of Collective Teacher Efficacy," School Effectiveness and School Improvement 17, no. 2 (2006): 179-99, https://doi.org/10.1080/09243450600565795.

${ }^{42}$ Rodica Mariana Niculescu and Mariana Norel, "Religious Education an Important Dimension of Human's Education," Procedia - Social and Behavioral Sciences 93 (2013): 338-42, https://doi.org/10.1016/j.sbspro.2013.09.200.

43 Ahmad Muradi, "Pengembangan Kompetensi Guru Bahasa Arab Melalui Imla Sebagai Organisasi Profesi," Arabi: Journal of Arabic Studies 1, no. 2 (2016): 1, https://doi.org/10.24865/ajas.v1i2.2.

44 Guo et al., "The Effects of Teacher Qualification, Teacher Self-Efficacy, and Classroom Practices on Fifth Graders' Literacy Outcomes."

45 Brian J.Caldwell, "Leadership in the Creation of World Class Schools: Beyond the SelfManaging School," in Leadership for Quality Schooling International Perspectives, vol. 1 (London and New York: Routledge, 2001), 145-63.

${ }^{46}$ Susan M. Printy, Helen M. Marks, and Alex J. Bowers, "Integrated Leadership: How Principals and Teachers Share Transformational and Instructional Influence," Journal of School Leadership 19, no. 5 (September 1, 2009): 504-32, https://doi.org/10.1177/105268460901900501; Nicoleta Dută and Elena Rafaila, "Training the Competences in Higher Education - A Comparative Study on the Development of Relational Competencies of University Teachers," Procedia - Social and Behavioral Sciences, International Conference: Education And Psychology Challenges - Teachers For The Knowledge Society - 2nd Edition EPC - TKS 2013, 128 (April 22, 2014): 522-26, https://doi.org/10.1016/j.sbspro.2014.03.199. 
Evaluation of teacher quality at SDI Qurrota A'yun Tulungagung is carried out weekly, semester, and annual. Meanwhile, the benefits of the teacher quality evaluation program include an increase in the rationality of teacher quality assessments and effectiveness of teacher quality assessments, improvement of teacher quality, and creation of material for consideration of neutrality in teacher development, following career policies or achievements. The activities carried out can be categorized based on knowledge, skills, feelings, consequences, and returns on investment. ${ }^{47}$

The following is what Robbins and Coulter said about the importance of assessment in determining the quality of human resources:

1. Management uses assessment to make personnel decisions, which provides information related to promotion, transfer, or dismissal

2. The assessment provides the needed training and development

3. Assessment can be used as a criterion for selection and development programs

4. Quality assessment to achieve feedback to workers. ${ }^{48}$

According to the above description, HRM in improving the quality of human resources effectively predicts obsolescence or underdevelopment of employee competencies in diversifying educators in facing global HR competition. It is demonstrated by the various program activities carried out, which impact individual teachers' achievements both regionally and nationally. This finding is expected to parse the Ministry of Education and Culture's research results, which explains that the feasibility of the number of principals and teachers in carrying out tasks and teaching is $84.82 \%$, while $15.18 \%$ is not feasible. ${ }^{49}$

Subsequently, a planned and sustainable increase in human resources will overcome the challenges of affirmative action, and improving teacher quality will maintain teacher commitment and encourage them to give their best performance to realize the institution's ideals.

${ }^{47}$ Lijan Poltak Sinambela and Sarton Sinambela, Manajemen Kinerja: Pengelolaan, Pengukuran Dan Implikasi Kerja (Depok: Rajawali Press, 2019). 392

${ }^{48}$ David A. DeCenzo, Human Resource Management. 243.

${ }^{49}$ Minister of Education and Culture, Analysis of Human Resources for Elementary and Secondary Edaucation 2015/2016 (Jakarta, Indonesia: Center for Education and Culture Data and Statistics, 2016), 3. 


\section{CONCLUSION}

HRM improves the quality of teachers in Islamic primary educational institutions in Indonesia to improve human resource quality. This improvement is to actualize the institution's vision and mission in response to global and market demands. Furthermore, Islamic primary educational institutions will improve the unity and dignity of educators through HRM, which is organized, precise, and committed to quality. HRM in improving the quality of teachers of Islamic primary education institutions in Indonesia requires stages that institutions must carry out, which include careful planning, continuous guidance by holding various on-the-job and off-the-job training programs, and lastly, carrying out periodic teacher quality evaluations. Subsequently, implementing qualitybased HRM in earnest will result in Islamic basic education institutions in Indonesia that are of high quality or excellence regarding institutional development.

Due to the early stages of the Covid-19 pandemic, the researchers had difficulty collecting data and research objects at only one institution. However, the next researcher should collect a larger sample to achieve satisfactory results and discover a model of HRM for improving the quality of teachers in general in Indonesia.

\section{ACKNOWLEDGMENTS}

Thank you to the SDI Qurrota A'yun institution for being the object of research. Thank you to Mr. Nur Kholis who has helped carry out research at the research site.

\section{DECLARATION OF CONFLICTING INTERESTS}

The author/s declared no potential conflicts of interest with respect to the research, authorship, and/or publication of this article.

\section{FUNDING}

Sources of funding in conducting research are independent.

\section{ORCID iD}

Makherus Sholeh iD http://orcid.org/0000-0002-2591-5253

Nur Kholis ID http://orcid.org/0000-0002-9719-0024 


\section{REFERENCES}

Allui, Alwiya, and Jolly Sahni. "Strategic Human Resource Management in Higher Education Institutions: Empirical Evidence from Saudi." Procedia - Social and Behavioral Sciences 235, no. October (2016): 361-71. https://doi.org/10.1016/j.sbspro.2016.11.044.

Bastas, Meryem, and Zehra Altinay. "Employment for Disability: Human Resources Management in Higher Education for Quality." International Journal of Disability, Development and Education 66, no. 6 (2019): 610-15. https://doi.org/10.1080/1034912X.2019.1643456.

Chadwick, Clint. "The Vital Role of Strategy in Strategic Human Resource Management Education." Human Resource Management Review 15, no. 3 (2005): 200-213. https://doi.org/10.1016/j.hrmr.2005.11.003.

DeCenzo, David A. Human Resource Management, 10th Ed. Hoboken, N.J: Wiley, 2010.

Dessler, Gary. Human Resource Management, Fourteenth Edition. Boston; Montréal: Pearson, 2015.

Diaz, Gabriel, and Maggioli. Teacher Centered Professional Development. Healthcare Executive. Vol. 21. Virginia: Association for Supervision and Curriculum Development (ASCD), 2004.

Dută, Nicoleta, and Elena Rafaila. "Training the Competences in Higher Education - A Comparative Study on the Development of Relational Competencies of University Teachers." Procedia - Social and Behavioral Sciences, International Conference: Education And Psychology Challenges - Teachers For The Knowledge Society - 2nd Edition EPC - TKS 2013, 128 (April 22, 2014): 52226. https://doi.org/10.1016/j.sbspro.2014.03.199.

Epstein, Alice L., and Gary H. Harding. "Chapter 48 - Management Styles and Human Resource Development." In Clinical Engineering Handbook (Second Edition), edited by Ernesto Ladanza, 308-20. Cambridge, Massachusetts: Academic Press, 2020. https://doi.org/10.1016/B978-0-12-813467-2.00049-3.

Fan, Di, Cherrie J. Zhu, Xinli Huang, and Vikas Kumar. "Mapping the Terrain of International Human Resource Management Research over the Past Fifty Years: A Bibliographic Analysis." Journal of World Business 56, no. 2 (2021). https://doi.org/10.1016/j.jwb.2020.101185.

Fauth, Benjamin, Jasmin Decristan, Anna Theresia Decker, Gerhard Büttner, Ilonca Hardy, Eckhard Klieme, and Mareike Kunter. "The Effects of Teacher Competence on Student Outcomes in Elementary Science Education: The Mediating Role of Teaching Quality." Teaching and Teacher Education 86 (2019): 102882. https://doi.org/10.1016/j.tate.2019.102882.

Guo, Ying, Carol Mcdonald Connor, Yanyun Yang, Alysia D Roehrig, and J Frederick. "The Effects of Teacher Qualification, Teacher Self-Efficacy, and Classroom Practices on Fifth Graders' Literacy Outcomes." The Elementary School Journal 107, no. 5 (2007): 499-503. https://doi.org/10.1086/518627.

Ismaili, Diturije, and Muharem Etemi. "Human Resources Management at South East European University as a New Model of Higher Education in the Republic of 
Macedonia." Procedia - Social and Behavioral Sciences 2, no. 2 (2010): 512529. https://doi.org/10.1016/j.sbspro.2010.03.833.

J.Caldwell, Brian. "Leadership in the Creation of World Class Schools: Beyond the SelfManaging School." In Leadership for Quality Schooling International Perspectives, 1:145-63. London and New York: Routledge, 2001.

Li, Ling, and Yan Liu. “An Integrated Model of Principal Transformational Leadership and Teacher Leadership That Is Related to Teacher Self-Efficacy and Student Academic Performance.” Asia Pacific Journal of Education 00, no. 00 (2020): 118. https://doi.org/10.1080/02188791.2020.1806036.

Marler, Janet H., and John W. Boudreau. "An Evidence-Based Review of HR Analytics." International Journal of Human Resource Management 28, no. 1 (2017): 3-26. https://doi.org/10.1080/09585192.2016.1244699.

Minister of Education and Culture. Analysis of Human Resources for Elementary and Secondary Education 2015/2016. Jakarta, Indonesia: Center for Education and Culture Data and Statistics, 2016.

Minister of Religious Affairs. "Guidelines for National Standards of Islamic Religious Education in Schools, Decree of Ministry of Religious Affair Number 22/2011." Ministry of Religious Affair, Indonesia, 2011.

Munastiwi, Erni, and Sri Puryono. "Unprepared Management Decreases Education Performance in Kindergartens during Covid-19 Pandemic." Heliyon 7, no. 5 (2021): e07138. https://doi.org/10.1016/j.heliyon.2021.e07138.

Muradi, Ahmad. "Pengembangan Kompetensi Guru Bahasa Arab Melalui Imla Sebagai Organisasi Profesi." Arabi: Journal of Arabic Studies 1, no. 2 (2016): 1. https://doi.org/10.24865/ajas.v1i2.2.

Nakpodia, E. D. "Human Resource Management in School Administration in Delta State Nigeria." Journal of Social Sciences 23, no. 3 (2010): 179-87. https://doi.org/10.1080/09718923.2010.11892827.

Niculescu, Rodica Mariana, and Mariana Norel. "Religious Education an Important Dimension of Human's Education." Procedia - Social and Behavioral Sciences 93 (2013): 338-42. https://doi.org/10.1016/j.sbspro.2013.09.200.

Nishimura, Trisha. "Effective Professional Development of Teachers: A Guide to Actualizing Inclusive Schooling." International Journal of Whole Schooling 10, no. 1 (2014): 19-42. https://eric.ed.gov/?id=EJ1016781.

Noe, Raymond A., Barry A. Gerhart, John R. Hollenbeck, and Patrick M. Wright. Human Resource Management: Gaining a Competitive Advantage. 9th ed. Boston: McGraw-Hill Education, 2014.

Prastowo, Andi. Metode Penelitian Kualitatif Dalam Perspektif Rancangan Penelitian. Yogyakarta: Ar-Ruzz Media, 2012.

President of the Republic of Indonesia. "Teachers and Lecturers, Law of the Republic of Indonesia No. 14/2005." State Secretariat of the Republic of Indonesia, 2005.

Printy, Susan M., Helen M. Marks, and Alex J. Bowers. "Integrated Leadership: How Principals and Teachers Share Transformational and Instructional Influence." 
Journal of School Leadership 19, no. 5 (September 1, 2009): 504-32. https://doi.org/10.1177/105268460901900501.

Rahmi, Elvi, Achmad Patoni, and Sulistyorini Sulistyorini. "The Management of Human Resources Development in Increasing the Quality of Islamic Education Institutions." Al-Ta Lim Journal 27, no. 2 (2020): 166-78. https://doi.org/10.15548/jt.v27i2.624.

Richard, Jack C., and C. Lockhart. Reflective Teaching in Second Language Classrooms. London: Cambridge University Press, 2000.

Robbins, Stephen P, and Mary Coulter. Management. Thirteenth. Boston: Pearson, 2016.

Robinson, Viviane M. J. "Embedding Leadership in Task Performance.” In Leadership for Quality Schooling. London and New York: Routledge, 2001.

Ross, John A., and Peter Gray. "Transformational Leadership and Teacher Commitment to Organizational Values: The Mediating Effects of Collective Teacher Efficacy." School Effectiveness and School Improvement 17, no. 2 (2006): 179-99. https://doi.org/10.1080/09243450600565795.

Rowley, Chris, and Keith Jackson. Human Resource Management: The Key Concepts. London: Routledge, 2010.

Shea, Deborah, Daniel S. Alemu, and M. Jacqueline Visser. "A Social Network Study of Transformational Teacher Influence." Teacher Development 24, no. 5 (October 19, 2020): 603-25. https://doi.org/10.1080/13664530.2020.1818614.

Sholeh Makherus, Achmad Patoni, and - Abd Aziz, "Peer Review Transformational Leadership: Principal's Idealized Influence in Improving Teacher Competence," Other (Tulungagung: -, 2021), http://repo.iain-tulungagung.ac.id/20906/.

Sinambela, Lijan Poltak, and Sarton Sinambela. Manajemen Kinerja: Pengelolaan, Pengukuran Dan Implikasi Kerja. Depok: Rajawali Press, 2019. 
Human Resource Management...

This page is intentionally left blank

36 | Al-Bidayah, Volume 13, Number 1, June 2021 